\title{
Determination of $\alpha$-Amylase, Trypsin and Lipase in Duodenal Fluid: Comparison of Methods
}

\author{
By J.C. M. Hafkenscheid, M. Hessels and E.W. van der Hoek*
}

Division of Clinical Chemistry and Division of Gastroenterology*, Department of Internal Medicine, St. Radboud Hospital, University of Nijmegen, Nijmegen, The Netherlands

(Received September 24, 1981/September 8, 1982)

Summary: The three most important enzymes present in duodenal fluid, $\alpha$-amylase, trypsin and lipase, were determined by two different methods. Various dilution fluids for these determinations were compared. Some kinetic data are described together with the reproducibility of the assays. For $\alpha$-amylase the Phadebas method was compared with an UV method. Trypsin was determined using an immunoreactive trypsin test and a titrimetric method, while lipase was determined with a titrimetric method and a Cu-soap method.

There was very good agreement between the two $\alpha$-amylase methods and between the two trypsin determinations. There was also good agreement between both lipase methods.

The advantages and disadvantages of all the methods are discussed.

Bestimmung von $\alpha$-Amylase, Trypsin und Lipase in Duodenalsaft:

Ein Vergleich von Methoden

Zusammenfassung: Die drei wichtigsten Enzyme im Duodenalsaft, $\alpha$-Amylase, Trypsin und Lipase, wurden mit zwei verschiedenen Methoden bestimmt. Es wird ein Vergleich zwischen verschiedenen Flüssigkeiten zur Verdünnung gezogen. Einige kinetische Angaben werden zusammen mit der Reproduzierbarkeit beschrieben. Für $\alpha$-Amylase wird ein Vergleich zwischen der Phadebas Methode und einer UV-Methode gezogen. Trypsin wurde mit dem Test auf immunoreaktives Trypsin und einer Titrationsmethode bestimmt, während Lipase mit einer Titrationsmethode und einer $\mathrm{Cu}$-Seifen-Methode bestimmt wurde. Der Vergleich von beiden $\alpha$-Amylase-Methoden war gut, ebenfalls zwischen beiden Trypsin- und beiden Lipase-Methoden.

Die Vorteile und Nachteile aller Methoden werden besprochen.

\section{Introduction}

During the last decade, knowledge of pancreatic pathology has become much more important. It is now generally assumed that the clinical diagnosis of pancreatic diseases is difficult. In addition to very modern techniques like computer tomography (CT) and endoscopic retrograde cholangio pancreatography (ERCP), relatively simple laboratory determinations can also be of great value. In particular these include the determination of $\alpha$-amylase (1,4- $\alpha$-D-glucan glucano-hydrolase EC 3.2.1.1), trypsin (EC 3.4.21.4) and lipase (triacylglycerol acylhydrolase EC 3.1.1.3) in serum. More information can be obtained when these catalytic activities are determined in duodenal fluid, which can be obtained after stimulation with secretin/pancreozymin or after a test meal. It is then possible to determine volume, $\mathrm{pH}$ and bicarbonate concentration of these fluids and the output of the various substances can also be quantitated.

Although determinations of amylase $(1-4)$, trypsin $(5-8)$ and lipase $(9-13)$ in serum have been described extensively, there is still a need for more information regarding the determination of these enzymes in duodenal fluid. In this communication we 
compare two methods of determination for each of the three important pancreatic enzymes. Because many of the samples obtained after a test meal were turbid, nephelometric or turbidimetric techniques could not be used. For $\alpha$-amylase, a colorimetric method (Phadebas) was compared with an UV method (maltotetraose as substrate). A titrimetric method for the determination of trypsin was compared with an immunoreactive trypsin determination. Lipase was determined with a titrimetric method and a Cu-soap method. We determined the relationship between the catalytic activity concentration and time of incubation and between the catalytic activity concentration and amount of sample used. Various dilution fluids for these 3 enzymes were compared together with the reproducibility of the methods. For each enzyme, a direct comparison of both methods is also described.

\section{Materials and Methods}

Duodenal fluid was taken from normal individuals and from patients with benign or malign pancreatic diseases. All samples were obtained by an oropharyngeal tube with its orifice at the duodenal jejunal transition. The pancreas was stimulated by a meal containing $18 \mathrm{~g}$ fat, $15 \mathrm{~g}$ protein and $45 \mathrm{~g}$ carbohydrate (Lundh-test (14)). After administration of the meal the duodenal fluid was collected during 4 periods of $30 \mathrm{~min}$. Thereafter the duodenum was continuously perfused with saline containing a nonabsorbable marker, polyethylene glycol $4000(5 \mathrm{~g} /)$.

The rate of the perfusion was $300 \mathrm{ml} / \mathrm{h}$. After $30 \mathrm{~min}$, when a steady state had been reached, the pancreas was stimulated by $i$. v. administration of sincalide $(0.04 \mu \mathrm{g} / \mathrm{kg}$ body weight), a synthetic octapeptide of cholecystokinin. The duodenal fluid was collected during 3 periods of $20 \mathrm{~min}$. The samples were collected in vials, placed in icewater and stored at $-20^{\circ} \mathrm{C}$.

\section{$\alpha$-Amylase}

A comparison was made between the Phadebas method $(15,16)$ and an UV method with maltotetraose as substrate (17). The first method is based on the hydrolysis of a water-insoluble, crosslinked, blue starch polymer into water-soluble blue starch fragments. After stopping the reaction with $\mathrm{NaOH}$ and centrifugation the absorbance of the clear blue supernatant was read at $620 \mathrm{~nm}$. The catalytic activity concentrations were read from the standard curve purchased from the manufacturer. Phadebas amylase tablets were obtained from Pharmacia, Nederland B.V.

The second method is based on the hydrolysis of maltotetraose by $\alpha$-amylase. During this hydrolysis $2 \mathrm{~mol}$ of maltose are released together with other hydrolysis products. Maltose can be converted with auxiliary enzymes to glucose-6-phosphate. This substance can be converted to 6-phosphogluconate in a NAD/NADH coupled reaction. Chemicals were obtained from Interchemie, Hilversum, The Netherlands.

All $\alpha$-amylase activities were determined at $37^{\circ} \mathrm{C}$.

All samples were diluted with a fluid containing $\mathrm{NaCl}$ (159 $\mathrm{mmol} / \mathrm{l})$, albumin $(2 \mathrm{~g} / \mathrm{l})$ and $\mathrm{CaCl}_{2}(20 \mathrm{mmol} / \mathrm{l})$ to an appropriate dilution. Both methods were carried out as recommended by the manufacturers. The activities are expressed in $\mathrm{kU} /$.

\section{Trypsin}

Trypsin was determined according to the method of Wiggins (5) and using an immunoreactive determination (radioimmunoassay (18)). The first determination is based on the catalytic properties of trypsin in which $\mathrm{N}-\alpha$-benzoyl- $L$-arginine ethylester is hydrolysed and the liberated $\mathrm{N}$-benzoyl- $L$-arginine is titrated with $\mathrm{NaOH}(0.04 \mathrm{~mol} / /)$. The titration was carried put manually at $30^{\circ} \mathrm{C}$ with a stopclock and a $\mathrm{pH}$ meter $(\mathrm{pH}$ meter 22 , Radiometer, Copenhagen, Denmark)

All samples were diluted by a known amount with an acetate buffer $(50 \mathrm{mmol} / \mathrm{l}$; $\mathrm{pH} 5.8)$ containing $\mathrm{CaCl}_{2}(4.5 \mathrm{mmol} / \mathrm{l})$.

The activities are expressed as.kU/1. The substrate was purchased from Merck, Darmstadt, F.R.G.

The second method is based on a radioimmunological principle. The reaction depends upon the competition for binding sites on trypsin-specific antibodies between unlabelled trypsin and ${ }^{[25}$ I $]$ trypsin. The radioactivity of the final precipitate was counted in a Micromedic systems (Ms 588) gamma counter. The test was carried out at room temperature according to the recommendations of the manufacturer. Trypsin-standards, purchased from the manufacturer, were used for the standard curve. Chemicals were obtained from Behringwerke, Marburg Lahn, F.R.G.

As dilution fluid a saline-phosphate buffer ( $\mathrm{pH} 7.4$ ) was used containing $\mathrm{NaH}_{2} \mathrm{PO}_{4}(6.4 \mathrm{mmol} / \mathrm{l}), \mathrm{Na}_{2} \mathrm{HPO}_{4}(53.0 \mathrm{mmol} / \mathrm{l}), \mathrm{NaCl}$ (159 mmol/i), EDTA-disodiumsalt $(3.8 \mathrm{mmol} / \mathrm{l})$ and albumin $(10 \mathrm{~g} /)$. This dilution is recommended by the manufacturer.

Results are expressed in $\mathrm{mg} / \mathrm{l}$.

Lipase

Lipase was determined by measuring the liberated fatty acids after hydrolysis of an olive oil suspension by the enzyme. The free fatty acids were determined by titration or by a Cu-soap method.

The titrimetric method used was that described by Näher (19) except for some slight modifications. As substrate a suspension of acacia (gum arabic powder) and neutralized olive oil was used. After sonification ( $3 \mathrm{~min}$; in ice) deoxycholic acid (13 mmol/l) and $\mathrm{NaCl}(10.7 \mathrm{mmol} / \mathrm{l})$ were added to the substrate suspension with colipase $(2.5 \mathrm{mg} / \mathrm{l})$ and the $\mathrm{pH}$ adjusted to 9.0 . After heating for $5 \mathrm{~min}$ at $30^{\circ} \mathrm{C}$ the sample was added and the amount of $\mathrm{NaOH}$ $(0.01 \mathrm{~mol} / \mathrm{l})$ necessary to keep the $\mathrm{pH}(9.0)$ constant 5,10 and $15 \mathrm{~min}$ after the beginning of the reaction was determined. In the second method the liberated fatty acids were determined as their Cu-salts according to the method of Verduin et al. (10).

The same substrate was used as in the first method except for the addition of tris $(33 \mathrm{mmol} / \mathrm{l})$. After incubation for $30 \mathrm{~min}$ the reaction was stopped by the addition of the $\mathrm{Cu}$-reagent. The absorbance was read at $520 \mathrm{~nm}$. Stearic acid in chloroform was used as standard in accordance with Verduin et al. (10).

Samples were diluted with albumin $(2 \mathrm{~g} /)$ to an appropriate dilution and used immediately.

The activities are expressed in $\mathrm{kU} / \mathrm{at} 30^{\circ} \mathrm{C}$ for both methods.

Colipase from pig pancreas was obtained from Boehringer, Mannheim, F.R.G. Reagent blank rates and sample blank rates were determined under all experimental conditions, and the catalytic activities were corrected for these blank rates. The nonabsorbable marker, polyethylene glycol, did not disturb the reaction rates.

All other chemicals were reagent grade and obtained from Merck, Darmstadt, F.R.G. and Baker Chemicals, Deventer, The Netherlands. 


\section{Results and Discussion}

$\alpha-$ Amylase

Table 1. shows the effect of various dilution fluids on the $\alpha$-amylase activity of duodenal fluid. For both methods the best dilution fluid was that recommended for the Phadebas amylase determination, which contains $\mathrm{NaCl}$, albumin and $\mathrm{CaCl}_{2}$. This dilution fluid was used for further experiments.

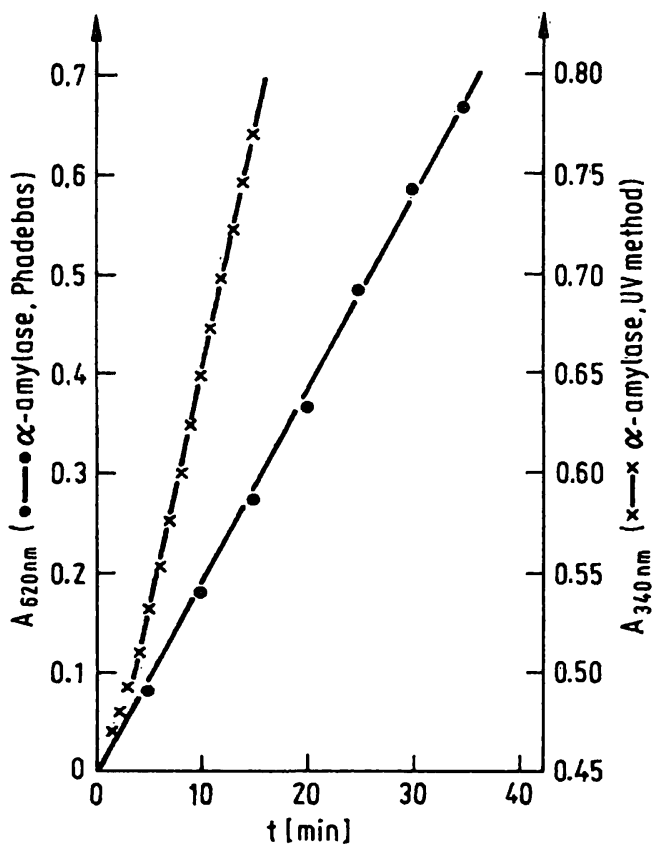

Figure 1 shows the time dependence of the enzymatic reaction. A linear relationship was obtained till 35 min after starting the reaction using the Phadebas method, but as far as the UV method is concerned linearity starts 5 min after the beginning of the reaction. Normally the difference in absorbance between 5 and $8 \mathrm{~min}$ after the start of the reaction was used for calculation of the catalytic activity concentration.

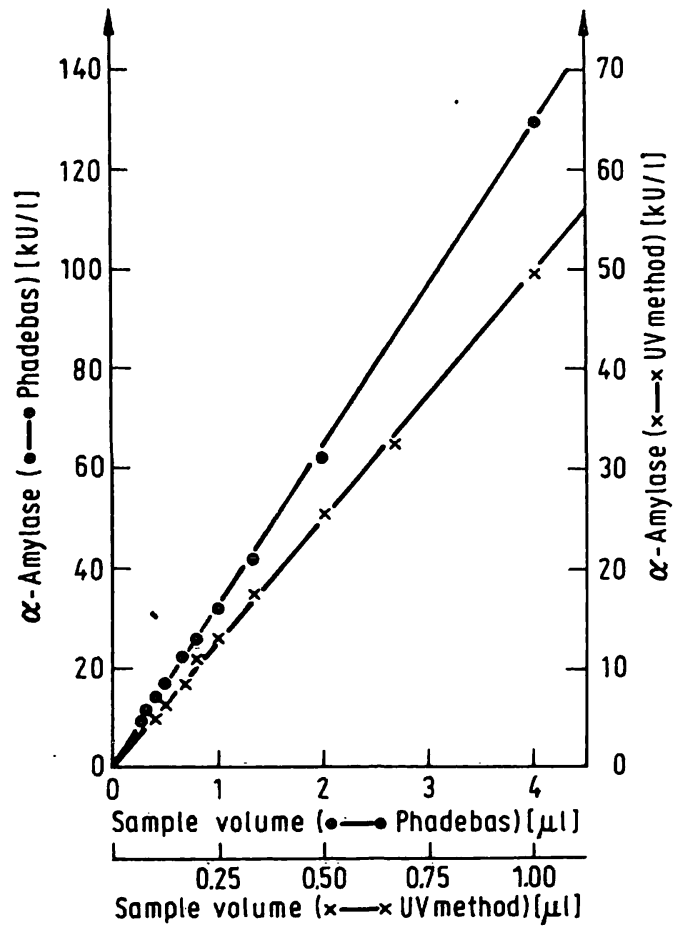

Fig. 1. Left: Time dependence of $\alpha$-amylase determination in duodenal fluid. (Mean of 6 determinations)

Right: Reaction rate as a function of the amount of sample added for $\alpha$-amylase assay in duodenal fluid. (Mean of 5 determinations)

Tab. 1. Various dilution fluids for $\alpha$-amylase determinations in duodenal fluid.

Concentrations:

$\mathrm{NaCl}: 159 \mathrm{mmol} /$; Albumin: $2 \mathrm{~g} / \mathrm{CaCl}: 20 \mathrm{mmol} / \mathrm{h}$ $\mathrm{n}=$ number of samples tested.

Differences between dilution fluids for the Phadebas method are all significant $(p<0.05)$.

Differences between dilution fluids for the UV method are only significant between dilution fluid 4 and the others. $(p<0.05)$

All other differences are not significant.

\begin{tabular}{lll}
\hline & $\begin{array}{l}\text { Phadebas method } \\
(\mathrm{kU} /) \\
\mathrm{n}=15\end{array}$ & $\begin{array}{l}\text { UV method } \\
(\mathrm{kU} /) \\
\mathrm{n}=9\end{array}$ \\
\hline $\begin{array}{l}\text { 1. Water } \\
\text { 2. } \mathrm{NaCl}\end{array}$ & 57.7 & 26.2 \\
3. Albumin & 73.4 & 30.0 \\
$\begin{array}{l}\mathrm{NaCl} \\
\mathrm{Albumin} \\
\mathrm{CaCl}\end{array}$ & 85.1 & 29.4 \\
$\begin{array}{l}\text { 5. } \mathrm{NaCl} \\
\mathrm{CaCl}\end{array}$ & 96.4 & 34.2 \\
$\begin{array}{l}\text { 6. } \\
\mathrm{NaCl} \\
\mathrm{Albumin}\end{array}$ & 78.3 & 31.9 \\
\hline
\end{tabular}

Figure 1 shows the reaction rate as a function of the amount of sample added. The reaction is linear up to $130 \mathrm{kU} / \mathrm{h}$ for the Phadebas method and $50 \mathrm{kU} / \mathrm{f}$ for the UV method.

Figure 2 shows the effect of the addition of $\mathrm{Ca}^{2+}$ to the dilution fluid. Although the effect is not large, the omission of $\mathrm{Ca}^{2+}$ in the Phadebas determination decreases the activity by about $10 \%$. There is a

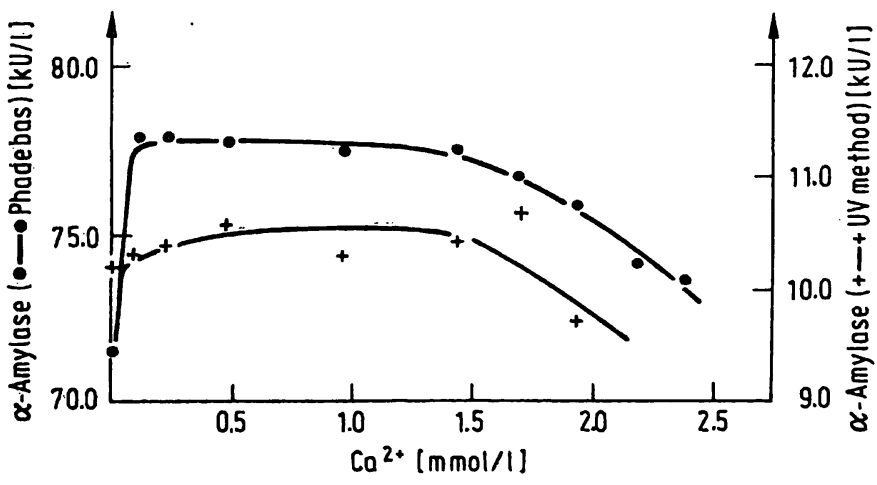

Fig. 2. Effect of $\mathrm{Ca}^{2+}$ added to the dilution fluid on the $\alpha$-amylase determination in duodenal fluid. (Mean of 4 deterninations) 
Tab. 2. Within-day and between-day variability for $\alpha$-amylase, trypsin and lipase of duodenal fluid.

Results are expressed as mean \pm S.D.

$\mathrm{n}=$ number of determinations

\begin{tabular}{|c|c|c|c|c|c|c|c|}
\hline & & Within-day & $\mathrm{CV}$ & $\mathrm{n}$ & Between-day & $\mathrm{CV}$ & $\mathrm{n}$ \\
\hline$\alpha$-Amylase & $\begin{array}{l}\text { Phadebas }(k U / l) \\
\text { UV method }(k U / l)\end{array}$ & $\begin{array}{r}177.3 \pm 2.4 \\
8.8 \pm 0.2\end{array}$ & $\begin{array}{l}1.4 \\
2.6\end{array}$ & $\begin{array}{l}8 \\
8\end{array}$ & $\begin{aligned} 131.7 & \pm 2.6 \\
22.3 & \pm 0.7 \cdot 1\end{aligned}$ & $\begin{array}{l}2.0 \\
3.0\end{array}$ & $\begin{array}{l}7 \\
7\end{array}$ \\
\hline Trypsin & $\begin{array}{l}\text { Titration method }(\mathrm{kU} / 1) \\
\text { Immunoreactive trypsin }(\mathrm{mg} / \mathrm{l})\end{array}$ & $\begin{array}{l}11.13 \pm 0.12 \\
577 \quad \pm 44\end{array}$ & $\begin{array}{l}1.1 \\
7.6\end{array}$ & $\begin{array}{l}11 \\
11\end{array}$ & $\begin{array}{l}11.57 \pm 0.28 \\
78 \pm .8\end{array}$ & $\begin{array}{r}2.4 \\
10.3\end{array}$ & $\begin{array}{l}6 \\
8\end{array}$ \\
\hline Lipase & $\begin{array}{l}\text { Titration method (kU/l) } \\
\text { Cu-soap method }(\mathrm{kU} / \mathrm{l})\end{array}$ & $\begin{array}{l}399.8 \pm 11.0 \\
520.5 \pm 20.8\end{array}$ & $\begin{array}{l}3.2 \\
4.0\end{array}$ & $\begin{array}{l}12 \\
10\end{array}$ & $\begin{array}{l}356.8 \pm 36.5 \\
471.6 \pm 24.0\end{array}$ & $\begin{array}{r}10.2 \\
5.1\end{array}$ & $\begin{array}{r}8 \\
10\end{array}$ \\
\hline
\end{tabular}

smaller effect of $\mathrm{Ca}^{2+}$ on the UV method. Concentrations of $\mathrm{Ca}^{2+}$ higher than $1.5 \mathrm{mmol} / \mathrm{h}$ in the reaction medium have an inhibitory effect on the $\alpha$-amylase activity. For convenience, we have always diluted the sample with a solution containing $20 \mathrm{mmol} / \mathrm{l}$ of $\mathrm{CaCl}_{2}$ corresponding to a concentration of 0.95 $\mathrm{mmol} / \mathrm{l}$ in the reaction medium.

The within-day and between-day variability is given in table 2 . Both are satisfactory and comparable with data reported for serum $(2,3,20)$.

The relationship between both $\alpha$-amylase determinations is given in figure 3 . The Phadebas method always gives higher catalytic activities than the UV method. The coefficient of correlation of 0.98 is good and comparable with 0.94 given by Meier et al.

(2) for serum.

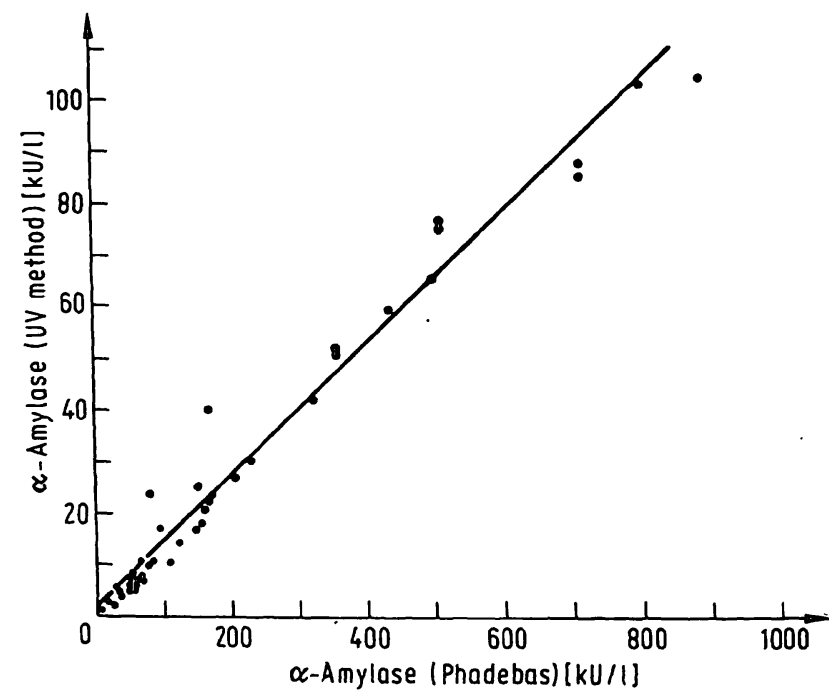

Fig. 3. Comparison of the Phadebas method and the UV method for the $\alpha$-amylase determination in duodenal fluid. $y=0.127 x+1.240 \quad r_{x y}=0.98 \quad n=44$

The ratio between both methods is $7.83 \pm 1.58$ for 44 duodenal samples. This ratio is somewhat higher than that obtained for serum, which is $5.72 \pm 0.95$ (own results), or 4.77 as reported by Hanson \& Yasmineh (4). Possibly the difference between these figures can be explained by the fact that the reactions are carried out at different temperatures.

\section{Trypsin}

The duodenal fluid has to be diluted for the determination of trypsin (tab. 3). For the titrimetric method, an acetate buffer containing $\mathrm{CaCl}_{2}$ is the best dilution fluid in agreement with Wiggins (5). This dilution fluid was used for further experiments. Of the solutions tested a phosphate buffer containing albumin appears to be the best dilution fluid for the immunoreactive trypsin determination in agreement with observations of Lake-Bakaar et al. (21). This phosphate buffer was used for the other experi-

Tab. 3. Various dilution fluids for trypsin determinations in duọdenal fluid.

Differences between dilution fluids for the titrimetric method are all significant $(\dot{p}<0.05)$, except for the difference between dilution fluid 5 and 6 .

Differences between dilution fluids for the immuñoreactive determination are all significant $(p<0.05)$ except for the difference between dilution fluid 2 and 3,2 and 5 and 3 and 5.

\begin{tabular}{|c|c|c|}
\hline & $\begin{array}{l}\text { Titrimetric } \\
\text { method } \\
(\mathrm{kU} /) \\
\mathrm{n}=9\end{array}$ & $\begin{array}{l}\text { Immunoreactive } \\
\text { trypsin } \\
(\mathrm{mg} / \mathrm{l}) \\
\mathrm{n}=6\end{array}$ \\
\hline 1. Water & 14.81 & 89 \\
\hline 2. $\mathrm{NaCl}(159 \mathrm{mmol} / \mathrm{l})$ & 15.95 & 224 \\
\hline 3. Albumin $(2 \mathrm{~g} / 1)$ & - & 250 \\
\hline 4. Phosphate buffer & - & 471 \\
\hline $\begin{array}{l}\mathrm{NaCl}(159 \mathrm{mmol} / \mathrm{l}) \\
\text { 5. Albumin }(2 \mathrm{~g} / \mathrm{l}) \\
\mathrm{CaCl}_{2}(20 \mathrm{mmol} / \mathrm{l})\end{array}$ & 17.36 & 306 \\
\hline $\begin{array}{l}\text { 6. Acetate buffer } \\
\mathrm{CaCl}_{2}\end{array}$ & 18.62 & - \\
\hline
\end{tabular}

phosphate buffer: $\mathrm{NaH}_{2} \mathrm{PO}_{4}: 6.4 \mathrm{mmol} /$; $\mathrm{Na}_{2} \mathrm{HPO}_{4}: 53.0 \mathrm{mmol} / \mathrm{h}$; $\mathrm{NaCl}: 159 \mathrm{mmol} / 1$; EDTA: $3.8 \mathrm{mmol} /$; albumin: $10 \mathrm{~g} /$; $\mathrm{pH}: 7.4$

acetate buffer: $50 \mathrm{mmol} / 1$; $\mathrm{CaCl}_{2}: 4.5 \mathrm{mmol} / \mathrm{l}$; $\mathrm{pH}: 5.8$ 

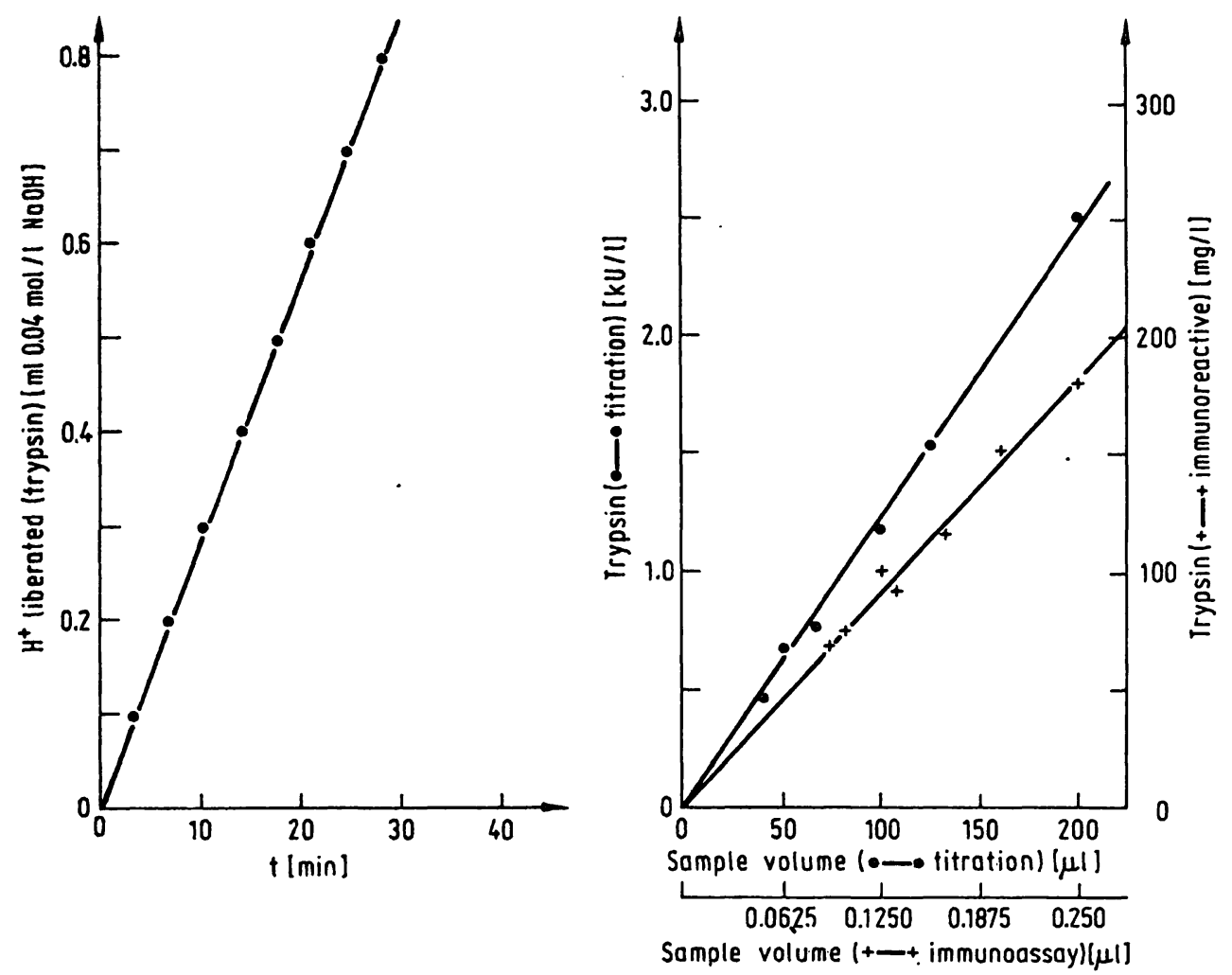

Fig. 4. Left: Time dependence of trypsin determination in duodenal fluid with the titrimetric method. (Mean of 3 determinations) Right: Reaction rate and immunoreactivity as a function of the amount of sample added for trypsin assay in duodenal fluid. (Mean of 2 determinations)

ments. The time relationship together with the dependence on the amount of sample added is given in figure 4; linear relationships were obtained.

As can be seen in figure 5 the addition of $\mathrm{Ca}^{2+}$ to the incubation medium of the titrimetric method is necessary in order to achieve complete hydrolysis. During the titration $0.75 \mathrm{mmol} / \mathrm{l}$ of $\mathrm{Ca}^{2+}$ is always present.

Table 2 gives within-day and between-day variability for the determination of trypsin by each method. The titration method shows better precision than the immunoreactive method.

A comparison of both methods for trypsin determination is given in figure 6 . The correlation coefficient

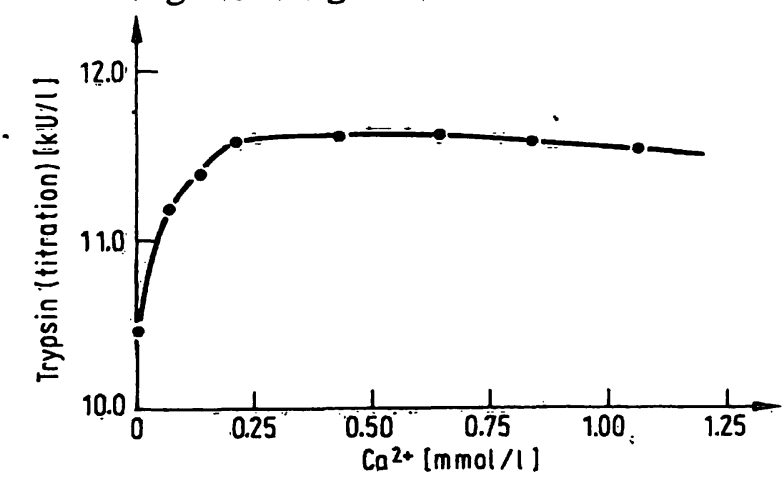

Fig. 5. Influence of $\mathrm{Ca}^{2+}$ on the titrimetric method for the trypsin determination in duodenal fluid. (Mean of 2 determinations) of 0.89 is good, especially when one takes into consideration the fact that the two methods are based on totally different principles. Our correlation coefficient is somewhat better than those reported by Lake-Bakaar et al. (21) for the comparison of the trypsin determination in duodenal juice by a spectrophotometric method and by the immunoreactive method.

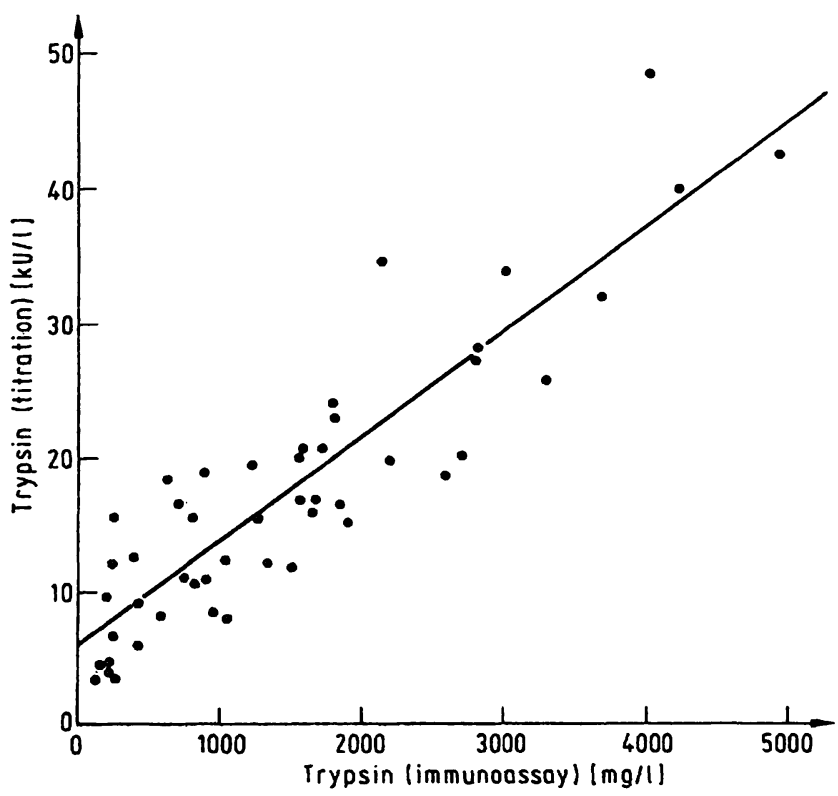

Fig. 6. Comparison of the titrimetric method and the immunoassay for the trypsin determination in duodenal fluid. $y=0.0079 x+5.75 r_{x y}=0.89 n=49$ 


\section{Lipase}

The effect of the addition of colipase in the lipase determination was investigated. By the titrimetric method the catalytic activity concentration in the absence of colipase was $275.8 \mathrm{kU} / \mathrm{h}$ and in the presence of colipase $353.8 \mathrm{kU} / \mathrm{h}(\mathrm{n}=6, \mathrm{p}<0.05)$; this represents an increase in activity of about $30 \%$. The same holds for the lipase determination carried out with the $\mathrm{Cu}$-soap method; $324.5 \mathrm{kU} / \mathrm{l}$ in the absence of colipase, and $600.7 \mathrm{kU} / \mathrm{h}$ in its presence $(\mathrm{n}=6$; $\mathrm{p}<0.05)$. Therefore, all determinations were carried out in the presence of colipase.

Table 4 shows the effect of various dilution fluids on the lipase activity of duodenal fluid; albumin seems to be the best dilution fluid so this dilution fluid was used for further experiments.

Figure 7 shows the time relationship for both lipase determinations. As far as the titrimetric method is concerned there is a linearity till $25 \mathrm{~min}$ after the onset of the reaction. The $\mathrm{Cu}$-soap method gives a straight line over an incubation period up to $60 \mathrm{~min}$ in contrast to Myrtle \& Zell (22), who observed linearity only till $10 \mathrm{~min}$ after the beginning of the reaction. Figure 7 also shows the reaction rate as a function of the amount of sample added.

The within-day and between-day variability is given in table 2. It can be seen that both methods give
Tab. 4. Various dilution fluids for lipase determinations in duodenal fluid.

$\mathrm{n}=$ number of determinations

Differences between dilution fluid 3 and the others for the titrimetric method are significant $(p<0.05)$. Other differences are not significant.

Differences between dilution fluid 1 a'nd the others for the $\mathrm{Cu}$-soap method are significant $(\mathrm{p}<0.05)$. Other differences are not significant.

\begin{tabular}{lll}
\hline & $\begin{array}{l}\text { Titrimetric method } \\
(\mathrm{kU} /) \\
\mathrm{n}=7\end{array}$ & $\begin{array}{l}\text { Cu-soap method } \\
(\mathrm{kU} / \mathrm{l}) \\
\mathrm{n} \equiv 5\end{array}$ \\
\hline 1. Water & 291 & 360 \\
2. $\mathrm{NaCl}(159 \mathrm{mmol} / \mathrm{l})$ & 295 & 464 \\
3. Albumin $(2 \mathrm{~g} / \mathrm{l})$ & 353 & 492 \\
$\begin{array}{l}\mathrm{NaCl}(159 \mathrm{mmol} / \mathrm{l}) \\
\mathrm{Albumin}(2 \mathrm{~g} / \mathrm{l})\end{array}$ & 288 & 469 \\
$\mathrm{CaCl}(20 \mathrm{mmol} / \mathrm{l})$ & & \\
\hline
\end{tabular}

good reproducibility. Tietz \& Fiereck (9) found a coefficient of variation of about $8 \%$ for the serum lipase determination according to a titrimetric method.

Figure 8 shows a comparison between the titrimetric method and the $\mathrm{Cu}$-soap method for the determination in duodenal fluid. There is a good correlation between both methods.
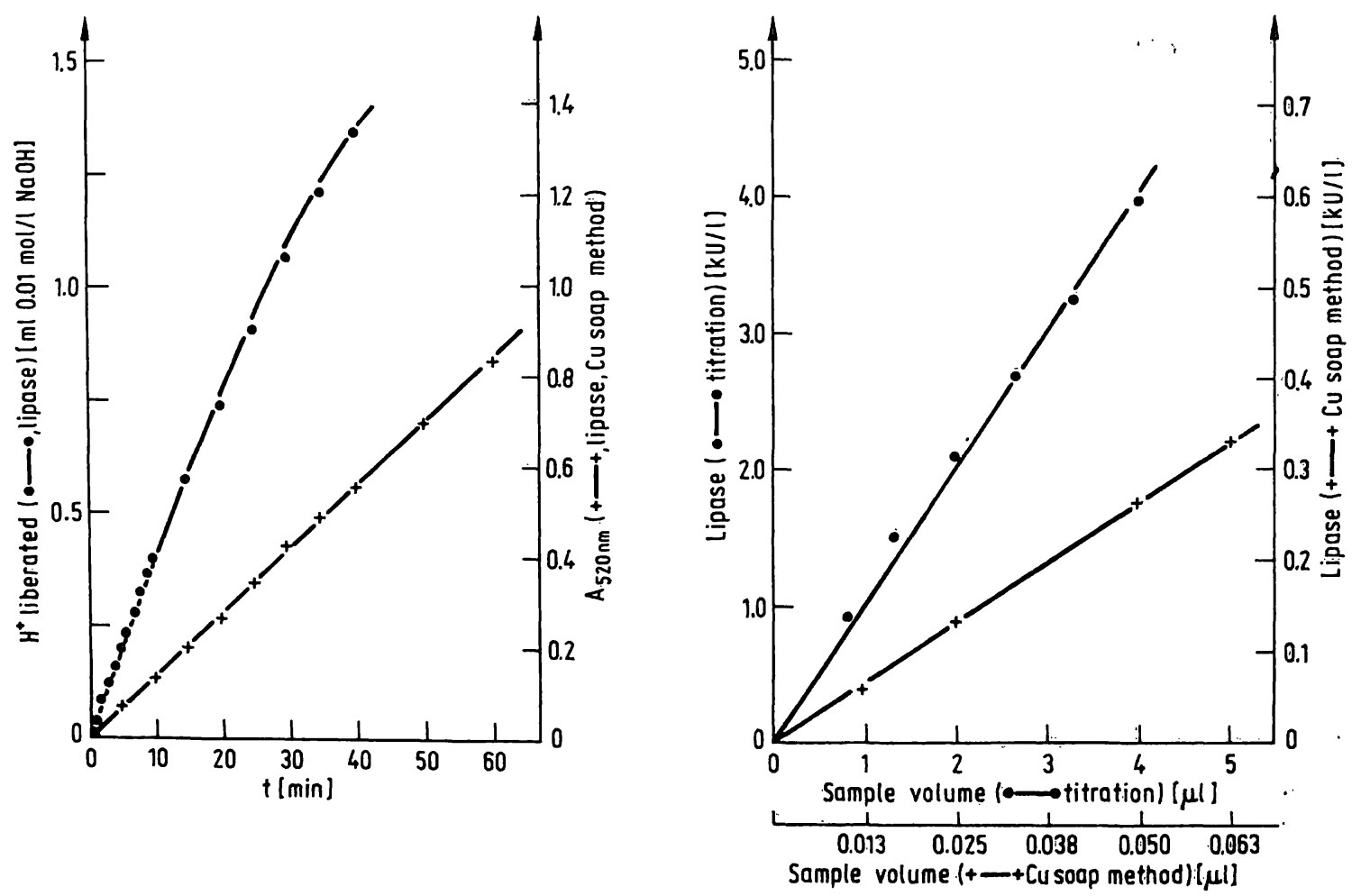

Fig. 7. Left: Time dependence of lipase determination in duodenal fluid. (Mean of 4 determinations)

Right: Reaction rate as a function of the amount of sample added for lipase assay in duodenal fluid. (Meani of 3 determinations) 
About two times higher catalytic activity concentrations were found with the $\mathrm{Cu}$-soap method than with the titrimetric method in contrast to the results of Kreutzer et al. (11), who observed just the opposite. Myrtle \& Zell (22) also reported a good correlation between both methods although their correlation was not linear. On the contrary Näher (19) observed the same catalytic activity concentrations for both methods. Generally different reaction conditions like temperature, $\mathrm{pH}$ of the incubation medium, incubation time, indicator, addition of deoxycholic acid were used by other authors, which hampers a direct comparison of the various methods.

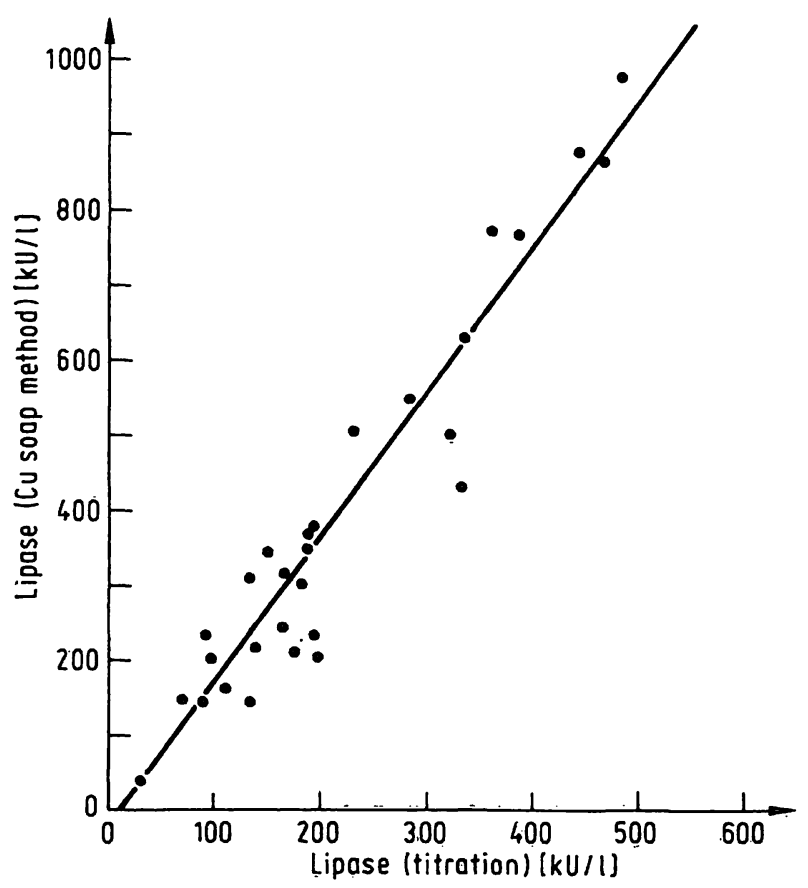

Fig. 8. Comparison of the titrimetric method and $\mathrm{Cu}$-soap method for the lipase determination in duodenal fluid. $y=1.97 x-33.1 \quad r_{x y}=0.96 \quad n=30$.

\section{Conclusion}

Table 5 gives a survey of some factors, which are important for the determination of $\alpha$-amylase, trypsin and lipase in duodenal fluid.

Generally, the precision of the methods is good. The number of determinations, which can be carried out in $1 \mathrm{~h}$ is rather different for each method. In this respect it is difficult to compare the different methods. It is obvious that all 6 methods investigated can be used for measuring the very' high catalytic activity concentrations which are present in duodenal fluid. It is not so easy to make a choice between the two methods in the three combinations tested.

As far as the $\alpha$-amylase is concerned, it seems that both methods are quite comparable. Only the costs of the chemicals are different for the Phadebas and UV method and could be a factor in favour of the Phadebas method. On the other hand the UV method is a continuous method, which is far preferable. The titrimetric method and the immunoreactive method for the determination of trypsin are also comparable. Although the titrimetric method is quite simple, only the enzymatically active part of the total trypsin is determined. Recently $O^{\prime}$ Connor et al. (23) reported some problems associated with the radioimmunoassay of trypsin in serum, especially the presence of serum protease inhibitors like $\alpha_{2}$ macroglobulin. As far as we know, these inhibitors are not present in duodenal fluid.

Because the $\mathrm{Cu}$-soap method is very laborious, we prefer the titration method for the determination of lipase. This method is relatively simple and cheap.

The conclusion seems justified that all the 6 methods tested are reliable for the determination of the catalytic activity concentrations of the enzymes mentioned in duodenal fluid, when the use of a turbidimetric or nephelometric method is not possible.

Tab. 5. Survey of some factors concerning $\alpha$-amylase; trypsin and lipase determinations in duodenal fluid.

\begin{tabular}{|c|c|c|c|c|c|c|}
\hline & \multicolumn{2}{|c|}{$\alpha$-Amylase } & \multicolumn{2}{|c|}{ Trypsin } & \multicolumn{2}{|c|}{ Lipase } \\
\hline & $\begin{array}{l}\text { Phadebas } \\
\text { - }\end{array}$ & UV method & $\begin{array}{l}\text { titrimetric } \\
\text { method }\end{array}$ & $\begin{array}{l}\text { immuno } \\
\text { reactive trypsin }\end{array}$ & $\begin{array}{l}\text { titrimetric } \\
\text { method }\end{array}$ & $\begin{array}{l}\text { Cu-soap } \\
\text { method }\end{array}$ \\
\hline Number of determinations & \pm 30 & \pm 20 & \pm 12 & - & \pm 5 & - \\
\hline Dilution of șample & yes & yes & yes & yes & yes & yes \\
\hline Reproducibility & good & good & good & moderate & good & good \\
\hline Linearity versus time & $0-35 \mathrm{~min}$ & $5-15 \min$ & $0-30 \mathrm{~min}$ & - & $0-25 \min$ & $0-60 \mathrm{~min}$ \\
\hline Linearity versus sample & good & good & good & good & good & good \\
\hline Equipment & photometer & $\begin{array}{l}\text { spectro- } \\
\text { photometer }\end{array}$ & pH-meter & $y$-counter & $\mathrm{pH}$-meter & photometer \\
\hline Agreement between both methods & \multicolumn{2}{|c|}{ good } & \multicolumn{2}{|c|}{ good } & \multicolumn{2}{|c|}{ gond } \\
\hline
\end{tabular}




\section{References}

1. Lehane, D. P., Wissert, P. J., Lum, G. \& Levy, A. L. (1977) Clin. Chem. 23, 1061-1065.

2. Meier, H., Henkel, E. \& Dankert, H., (1979) J. Clin. Chem. Clin. Biochem. 17, 709-716.

3. Whitlow, K. J., Gochman, N., Forrester, R. L. \& Wataji, L. J. (1979) Clin. Chem. 25, 481-483.

4. Hanson, N. Q. \& Yasmineh, W. G. (1979) Clin. Chem. 25, 1216-1221.

5. Wiggins, H.S. (1967) Gut 8, 415-416.

6. Koop, H., Lankisch, P. G., Stöckmann, F. \& Arnold, R. (1980) Digestion 20, 151-156.

7. Stagg, B. H. \& Wood, T. P. (1979) Ann. Clin. Biochem. 16, 147-151.

8. Koehn, H. D. \& Mostbeck, H. (1981) Clin. Chem. 27, 502.

9. Tietz, N. W. \& Fiereck, E. A. (1966) Clin. Chim. Acta 13, $352-358$.

10. Verduin, P. A., Punt, J. M. H. M. \& Kreuzer, H. H. (1973) Clin. Chim.. Acta 46, 11-19.

11. Kreutzer, H. H., Pennings, A. W., Punt, J.M. H. M. \& Verduin, P. A. (1975) Clin. Chim. Acta 60, 273-279.

12. Rick, W. (1969) J. Clin. Chem. Clin. Biochem. 7, 530-539.
13. Yang, J. S. \& Biggs, H. G. (1971) Clin. Chem. 17, 512-518.

14. Lundh, G. (1962) Gastroenterology 42, 275-280.

15. Ceska, M., Birath, K. \& Brown, B. (1969) Clin. Chim. Acta $26,437-444$

16. Soininen, K., Härkönen, M., Ceska, M. \& Adlercreutz, $H$. (1972) Scand. J. Clin. Lab. Invest. 30, 291-297.

17. Pierre, K. J., Tung, K. K. \& Nadj, H. (1976) Clin. Chem. 22, 1219.

18. Elias, E., Redshaw, M. \& Wood, T. (1977) Lancet $I I, 66=68$.

19. Näher, G. (1974) In: Methoden der enzymatischen Analyse (Bergmeyer, H. U., ed.) 3. neubearbeitete und erweiterte Auflage. Verlag Chemie Weinheim/Bergstr. 843-853.

20. Kaufman, R. A. \& Tietz, N. W. (1980) Clin. Chem. 26, 846853.

21. Lake-Bakaar, G., McKavanagh, S., Rubio, C. E., Epstein, O. \& Summerfield, J. A. (1980) Gut 21, 402-407.

22. Myrtle, J. F. \& Zell, W. J. (1975) Clin. Chem. 21, 14691473.

23. O'Connor, C. M., O'Donnell, M.D. \& Mc Geeney, K. F. (1981) Clin. Chim. Acta 114, 29-35.

Dr. J. C. M. Hafkenscheid Laboratory for Clinical Chemistry Department of Internal Medicine St. Radboud Hospital University of Nijmegen Nijmegen, The Netherlands 